\title{
The Effect of Skill Variety, Task Identity, Task Significance, Autonomy and Feedback on Job Performance
}

\author{
Syamsul Hadi Senen, Sumiyati, Masharyono \\ Universitas Pendidikan Indonesia \\ syamsulhadisenen@upi.edu
}

\begin{abstract}
Dynamic factor in organization nonprofit oriented and profit or the human resources have a high performance in which will determine forward the organization. One of them nonprofit organization that college in which the performance of employees is low. If not improved it would impact on reaching its objectives organization. The purpose of this research was understand the influence of skill variety, task identity, task significance, autonomy and feedback on performance employees. Methods used the explanatory survey. The subject in this study was 69 honorary employees at Universitas Pendidikan Indonesia. The survey was complicated by questionare and analysis techniques data using with SPSS. The results showed skill variety affected to job performance. While task identity, task significance, autonomy, and feedback there is no the effect on job performance. There for task identity, task significance, autonomy, and feedback there is no the effect on job performance.
\end{abstract}

Keywords-skill variety, task identity, task significance, otonomy, feedback, and job performance

\section{INTRODUCTION}

One of resources which is the most important assets organization is human resources [1], because human resources plays a role in achieving the objective organization [2]. Human resources is the factor dynamic forward capable of determining or the withdrawal of an organization, so that agencies with human resources are reliable will win over the competition. Competition between companies was not a rivalry between machine, among the building, even among equipment nor competition between the capitals. In substance the competition exists between personnel. The company which has personnel who better, is a company that will win over the competition [3]

Employee performance is something very important in the organization efforts to achieve its goal [4]. The scale of priority management namely parties with the performance which significant employees. Empowerment want cause employee have to good performance, so employee must give contribution to organization growth higher. Several management expert to said, that empowerment want to give purpose for organization [5].

Problems the employee performance is still a key issue in various private good organization or public. There still employees who rarely finish work not just in time $29,1 \%$ and employees not appropriate in finish the job of 24,5\% [6]. Employees knowledgeable about characteristic of his work will help offical in finish the job that the employee performance good will [7]. Job characteristics were related to volunteers' autonomous motivation, satisfaction and performance [8]. The Hackman-Oldham theory of job design, are regarded as suggestive evidence that enrichment can cause substantial improvements in employee attitudes, but that these benefits may not lead to greater productivity. It is argued that in order to explain the effect of enrichment on performance, it is necessary to consider other factors besides the psychological states produced by jobs which are seen to have certain characteristics [9]. There for skill variety, task identity, task significance, autonomy and feedback influences the performance employees?

\section{LITERATURE REVIEW}

\section{A. Job Characteristics}

The concept of job characteristic can be found on the work job enrichment as one part of the work redesign or job design. Job enrichment is practice of constructing the motivation into the job content [10].

Job characteristics or specifications of jobs is working conditions must be fulfilled so can carry out a job or office [11]. Job characteristics having a job when the person can learn (knowledge of result) that he or she has performed well on tasks (experienced responsibility) that she or he cares about (experience meaningfulness). In addition this situation result in certain outcomes that are beneficial to the employer [12].

\section{B. Aspects Job characteristics}

The dimensions of job characteristics is Skill Variety, Task identity, Task Significance, Autonomy, and Feedback [13]

\section{Job Performance}

Human resources continue as an essential element in a company or organization, hence human resources pay attention carefully. In a company employees work according to the tasks and the responsibility to him. Whether this responsibility not capable of carried out well, this can be seen from performance they had not can meet the criteria. Performance was a result of 
working or also work performance produced by an employee in accordance with talent.

Performance lead to a work done in order to achieve better achievement [14]. Performance is indeed often regarded as simply the outcomes achieved: a record of a person's accomplishments [15]. Job performance is the outcomes of jobs that relate to the purposes of the organization such as quality, efficiency, and other criteria of effectiveness [16].

\section{Dimensions performance}

Dimensions performance consist of [12]:

1. Quality of work, The quality of work to be accomplished in accordance with ketentuan-ketentuan or requirement .Employees have to give priority to quality of work undertaken, in this case employees did work must examine them and in accordance with the established rules .Indicators the value of the obtained employee of the work is according to the standard provisions to companies.

2. Quantity of work performed, Namely the amount of work done in a period of time

3. Interpersonal effectiveness, Namely on personality, leadership, hospitality and personal integrity.This d focus on individual as intensity employees in cooperation with colleagues, intesitas employees discuss in terms of occupation, and capable of working with teamwork.

Aspects criteria performance according namely [17]:

1. Quantity of Work, The amount of work to be done by employees in a period of time .The number of jobs provided in accordance with employees capability. Indicators that deals with the number of hours of work done in a period of time prescribed. Willingness of loyalty and employees to work exceeding working hours that is with the agreement that has been specified

2. Quality of Work, The quality of work achieved based on require way and high he will in turn bore awards and progress and expansion organization start increased knowledge and skill systematically according to the science and technology growing rapidly.

3. Job Knowledge, How extent knowledge about the jobs employees and skills. Indicator dealing with extent of information about job and skill owned employees and employee's ability to keep floated away with knowledge of better.

4. Creativeness, The authenticity of the idea which is raised of steps to solve the problems arising. Indicators that deals with the authenticity of ideas which is raised of steps to solve the problems arising.

5. Cooperation, Willingness to cooperate with others ( a fellow member ) organization .Those relating to the process of adapting the workplace and willingness to cooperate with others

6. Dependability, Awareness and trustworthy in attendance. The discipline awareness and trustworthy in terms of employment and resolution just in time.

7. Initiative, Spirit to perform tasks new in enlarging responsibility

8. Personal Qualities, Leadership and of personal integrity of. Related to personality, leadership, hospitality, and of personal integrity of. This indicator more specific because individuals is the and the pattern think different.

\section{E. Performance Measure}

The performance indicators that must be managed well tied with the management of employees covering: feedback 360 degrees, absentee, application and vacancy, the availability of training, consider the appeal internal, cost efficiency of training, motivation and commitment, ideas or advice building, productivity employees, worker satisfaction goes, worker satisfaction goes against training program, loyalty employees, the new training program, the frequency of the audit for expertise, each employee bill calculation, the influence of training programs against the company or organization, the internal promotion, the number of interview any work offered, concern for vision and mission company, skill double, flexibility workers, the qualifications, a rejection of work offered, consider the appeal remuneration and benefit given company, the availability of expertise, the use of expertise employee who held firm durab [18].

\section{F. The Obstacles In The Assessment}

Companies with various assess performance employees, as assessor often find obstacles including:

1. Hallo effect,

2. Leniency,

3. Strictness,

4. Central tendency,

5. Personal bias

\section{RESEARCH METHODOLOGY}

The object of this study the skill variety, task identity, task significance, autonomy, and feedback and performance employees. But the subject of study is honorary administration employees Universitas Pendidikan Indonesia. The population of the research is 69 employees. Data Analysis techniques used use path analysis with help SPSS. The hypothesis in this research are the influence of skill variety, identity of a task significance of a task, autonomy, and feedback affect the employee performance. 


\section{THE RESULTS OF RESEARCH}

Table I response recapitulation of the respondent can be seen that significance in duty obtains a judgment the greatest of the respondents is as much as $85,51 \%$ and at least who feel variation skill of 77, $97 \%$. Task Significance is a levels where work is an important involves the contribution which means over organization or society in general and Variation skill is a scale at which occupation requires variation activity different in finish the job involving a number of skills and talent different than workers [13]. There for the company must consider variation skill and significance duty in improve performance [8].

TABLE I. RESPONSE RECAPITULATION OF THE RESPONDENTS

\begin{tabular}{ccc}
\hline No & Indicator & $\%$ \\
\hline 1 & Skill variety & 77,97 \\
2 & Task identity & 82,46 \\
3 & task significance & 85,51 \\
4 & Otonomy & 79,42 \\
5 & Feedback & 82,46 \\
\hline
\end{tabular}

a. Source: data processing 2013

Table 2 Recapitulation Of The Responses The Respondents Regarding Job Performance. Based on the research done dependability indicators get the most of the respondents a month $90,14 \%$ and the lowest respondents judge creativeness of $83,62 \%$. Human resources remains an essential element in a company or organization, hence human resources pay attention carefully [2013]. In a company employees work according to the tasks and the responsibility to him. Whether this responsibility cannot be implemented well, this can be seen from performance they could not be meet the criteria. Performance is the result of labor or also work performance produced by an employee in accordance with this talent [14][15][16].

TABLE II. RECAPITULATION OF THE RESPONSES THE RESPONDENTS REGARDING JOB PERFORMANCE

\begin{tabular}{ccc}
\hline No & Indicator & $\%$ \\
\hline 1 & Quantity of Work & 85,94 \\
2 & Quality of Work & 89,57 \\
3 & Job Knowledge & 86,09 \\
4 & Creativeness & 83,62 \\
5 & Coooperation & 88,26 \\
6 & Dependability & 90,14 \\
7 & Initiative & 85,36 \\
8 & Personal Qualaities & 89,13 \\
\hline
\end{tabular}

On this research there are five hypothesis that will be in the test, namely the influence of skill variety, task identity, task significance, autonomy, feedback systems against job performance. Based on the results of the testing of hypotheses obtained:

1. There are skill variety influence on employee performance
2. There are task identity influence on employee performance

3. There are task significance influence on employee performance

4. There are autonomy influence on employee performance

5. There are feedback influence on employee performance.

\section{CONCLUSIONS AND SUGGESTIONS}

\section{A. Conclusions}

Based on the results of response respondents significance in duty especially in matters work done influential to the work of others so that it should be done by quickly and correctly was assessed as the high .While who are assessment at least that is autonomy especially in matters organization provide opportunities to make your own decisions pertaining to duties that will be completed.

Based on the results of response respondents had of job performances, who get assessment the highest for indicators dependability especially in has awareness of tasks that given. While indicators who are assessment at least that is creativeness especially in terms of occupation need creativity high.

Is the skill variety of job performance paid by honorarium administration Universitas Pendidikan Indonesia? And not is the skill variety, task identity, task significance, autonomy and feedback to job performance paid by honorarium administration Universitas Pendidikan Indonesia

\section{B. Suggestions}

Job Characteristics is the factor that show the characteristics of a job or a type of factors that distinguish between one occupations with other forms of work. In this matter that need to be improved namely autonomy especially in terms of organization provide opportunities to make your own decisions relating to the duties that will be completed.

The employee performance is the result of a process or a set of the process that creates shared understanding about what must be achieved ( and how it attainable ) and how people can arrange in a manner that can increase the likelihood of this aim.

In this matter that need to be improved namely creativeness especially in matters of occupation requires creativity that high. May need to further improve task identity, task significance, and autonomy and feedback systems with holding training or development in an effort to improve job performance.

\section{REFERENCES}

[1] Yeh, Hueryren. 2012. The Mediating Effect of Organizational Commitment on Leadership Type and Job Performance. The Journal 
of Human Resource and Adult Learning, Vol 50. 8, Num. 2, December 2012.

[2] Sohail, et al. 2014. Effect of Work Motivation and Organizational Commitment on Job Satisfaction: (A Case of Education Industry in Pakistan). Global Journal of Management and Business Research: A Administration and Management Volume 14 Issue 6.

[3] Nitisemito, Alex S, Personnel Management, Jakarta: Ghalia Indonesia. 1996.

[4] Rivai, Veithzal, Human Resources Management for Company, Jakarta: PT Rajagrafindo Persada.2005

[5] Blanchard K, Carlos JP, Randolph A. Empowerment takes more than a minute. Berrett-Koehler Publishers; 2001 Oct 1.

[6] Masharyono and Senen SH. Analysis Job Performance Honorary Administration with Competency And Job Characteristics In Support Of Reach Leading And Outstanding Universitas Pendidikan Indonesia. Fokus Ekonomi. 2015 Dec 1;10(2):120-37.

[7] Syamsul Hadi Senen, Sumiyati, and Masharyono. Analysis Job Performance Honorary Administration with Competency And Job Characteristics In Support Of Reach Leading And Outstanding Universitas Pendidikan Indonesia. 2013.

[8] Millette V, Gagné M. Designing volunteers' tasks to maximize motivation, satisfaction and performance: The impact of job characteristics on volunteer engagement. Motivation and Emotion. 2008 Mar 1;32(1):11-22.
[9] Orpen C. The effects of job enrichment on employee satisfaction, motivation, involvement, and performance: A field experiment. Human Relations. 1979 Mar 1;32(3):189-217.

[10] Influence of Work Environment, Job Transfers and Job Characteristics on Employee Morale (PNS Employee Survey on the Environment Disbudpar Jabar). 2011.

[11] Rivai, Veithzal dan Ella Jauvani S. 2009. Human Resources Management For Companies To Practice Of The Theory, Edition I, Jakarta: PT. Raja Grafindo Persada.

[12] Gomez-Mejia, Luis R, David B. Balkin, Robert L. Cardy. Managing Human Resources. Manufactured in the United States of America: Pearson Education, Inc., publishing as Prentice Hall. 2012.

[13] Robbins, P. Stephen dan Mery Coulter. Management. Prentice Hall One Lake Street: Perason Education Inc. 2012.

[14] Usman, Husaini. Management. Theory, Practices and Education Research. Jakarta: PT. Bumi Aksara. 2010.

[15] Amstrong, Michael. Human Resource Management Practice. Great Britian and The United States: Kogan Page Limited. 2010

[16] Gibson, James L, John M. Ivancevich, James H. Donnell. Jr, Robert Konopaske. Organizations: Behavior, Structure, Processes, Fourteen Edition. New York: McGraw-Hill, Inc. 2012.

[17] Gomes, C. Faustino. Manajemen Sumber Daya Manusia.Yogyakarta: Andi Offset. 2010

[18] Wibisono, Dermawan. Performance management corporate and organization. Jakarta: Erlangga. 2011 